\title{
Glosa aprobująca do wyroku TK z dnia 7 marca 2018 r., sygnatura akt K 2/17
}

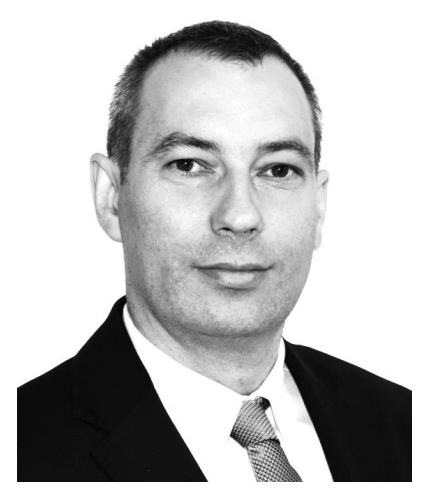

\section{Stawomir Pawtowski}

Profesor Uniwersytetu im. Adama

Mickiewicza w Poznaniu, gdzie pracuje w Katedrze Prawa Administracyjnego i Nauki o Administracji.

$\triangle$ womir@amu.edu.pl

https://orcid.org/oooo-0002-2060-6638

\author{
An Approving Commentary \\ to the Sentence of the Constitutional \\ Tribunal of 7.03.2018, ref. K 2/17
}

The subject of this gloss is a landmark ruling of the Constitutional Tribunal (CK) regarding one of the institutions of antiquity - preclusion. These issues in Polish administrative law are still controversial, and the views often differ significantly. The voted judgment deserves attention because it has not been explicitly stated in Polish jurisprudence for a long time that the rules in force in civil (general) law cannot be directly applied in public (special) law. CK argues that the justification of the institution of antiquity cannot be identical in public law as in private law, because the legal relations are vertical in the first and horizontal in the second. The indicated inequality of participants in the legal relationship and the possession of a professional clerical apparatus caring for the interests of the State, including property, means that the classic justification of the institution of antiquity, in particular the stabilizing and evidentiary function, are not a sufficient justification for using the preclusion. This is all the more justified when public law interference in property rights occurs without due warranty rights.

Słowa kluczowe: przedawnienie, terminy zawite, ograniczenie prawa własności, prawo własności, równowaga budżetowa

Key words: expiration, prescription period, property rights, restriction of property rights, budget balance

https://doi.org/10.32082/fp.v2i52.214

W wyroku Trybunału Konstytucyjnego z dnia 7 marca 2018 r. ${ }^{1}$ przedmiotem rozważań było zagadnienie, które w prawie administracyjnym ciągle należy do nierozstrzygniętych, a stawiane

1 Wyrok TK z dnia 7 marca 2018 r., K 2/17, OTK-A 2018, poz. 13. tezy wielokroć nie dotykają istoty problemu. Mowa tu w ogólności o instytucji dawności, a w szczególności o prekluzji, która w prawie cywilnym nie budzi tak wielu kontrowersji jak w prawie publicznym. Wynika to przede wszystkim z tego, że w tym ostatnim brak jest ogólnych reguł jej stosowania. 
Taki stan rzeczy nie pozostał bez oddźwięku w doktrynie. Wskazać można chociażby projekt przepisów ogólnych prawa administracyjnego z 2007 r., w którym część przepisów poświęcono wprost tej problematyce, w szczególności art. 29². Zapewne ze względu na doniosłość tego zagadnienia oraz brak zgody co do ogólnych kierunków wykładni w ostatnim czasie pojawiły się dwa opracowania, które starają się holistycznie przedstawić jego złożoność. Mowa tu o monografiach Wojciecha Piątka ${ }^{3}$ i Mirosława Wincenciaka ${ }^{4}$.

Nadto glosowane orzeczenie zasługuje na uwagę także z tego względu, że nie tylko wypowiada się wprost w przedmiocie jednej z instytucji dawności, ale wskazuje nowe kierunki wykładni z naczelną tezą, że uzasadnienie jej stosowania w prawie publicznym (administracyjnym) nie może być tożsame z prawem cywilnym.
- art. 64 ust. 1 w związku z art. 31 ust. 3 i w związku $\mathrm{z}$ art. 64 ust. 3 Konstytucji,

- art. 2 Konstytucji,

- art. 1 Protokołu nr 1 do Konwencji o ochronie praw człowieka i podstawowych wolności (Protokół nr 1 do EKPC),

- art. 64 ust. 2 w związku z art. 32 ust. 1 Konstytucji.

Główną osią sporu był krótki, gdyż zaledwie 2-letni termin (materialny) na złożenie wniosku o ustalenie i wypłatę odszkodowania lub wykup nieruchomości w sytuacji, gdy wskutek wejścia w życie rozporządzenia lub aktu prawa miejscowego powodującego ograniczenie sposobu korzystania z nieruchomości lub jej części korzystanie z niej w dotychczasowy sposób lub zgodny z dotychczasowym przeznaczeniem stało

\title{
Uzasadnienie stosowania instytucji dawności
} w prawie publicznym (administracyjnym)

\author{
nie może być tożsame z prawem cywilnym.
}

W wyroku TK z dnia 7 marca 2018 r. przedmiotem sporu był art. 129 ust. 4 Ustawy z dnia 27 kwietnia 2001 r. - Prawo ochrony środowiska (p.o.ś.) $)^{5}$ a zapadłe orzeczenie jest konsekwencją wniosku Rzecznika Praw Obywatelskich (RPO) z 2017 r. ${ }^{6}$ o zbadanie zgodności tego przepisu z:

2 Projekt z dnia 29 grudnia 2010 r., druk nr 3942, Sejm RP VI kadencji, http://orka.sejm.gov.pl/Druki6ka.nsf/0/8F21 C6C714261B99C1257849003B79D6/\$file/3942.pdf (dostęp 13.11.2019).

3 W. Piątek, Przedawnienie w prawie administracyjnym, Poznań 2018.

4 M. Wincenciak, Przedawnienie w polskim prawie administracyjnym, Warszawa 2019.

5 T.j. Dz.U. 2018, poz. 799 z późn. zm.

6 Wniosek Rzecznika Praw Obywatelskich z dnia 24 lutego 2017 r., sygn. IV.7002.55.2014.ZA, https://www.rpo.gov.pl/ $\mathrm{pl} /$ content/rzecznik-zlozyl-wniosek-do-trybunalu-konstytucyjnego-w-sprawie-terminu-ubiegania-sie-o-rekompensate (dostęp 9.07.2019). się niemożliwe lub istotnie ograniczone. Jak wprost zauważa TK, do RPO wpływały liczne skargi obywateli, że wprowadzony termin materialny zgłoszenia roszczenia mający charakter prekluzyjny ${ }^{7} \mathrm{w}$ istocie oznacza niemożność dochodzenia rekompensat ${ }^{8}$. Nadto RPO w kontekście ogólnej refleksji o prekluzji podniósł, że zasada ius civile vigilantibus scriptum est nie może stanowić uzasadnienia do wprowadzenia tak surowych konsekwencji. Mimo że tezę tę uzasadnia, to jednak nie odnosi się zdaniem Autora do kwestii pierwszoplanowej w tym względzie, mianowicie - czy regułę właściwą dla prawa cywilnego można stosować również w prawie publicznym.

\footnotetext{
7 Zob. M. Wincenciak, Przedawnienie..., dz. cyt., s. 112, o terminie zawitym prawa materialnego wypowiada się także na s. 304-310; zob. także W. Piątek, Przedawnienie..., dz. cyt., s. $196-197$.

8 K 2/17, pkt. 2.1.
} 
W pierwszej kolejność TK zasadnie zauważył, że art. 129 ust. 4 p.o.ś. nie stanowi bezpośredniego ustawowego ograniczenia prawa własności i innych praw majątkowych. Ograniczenia takie bowiem wypływają bezpośrednio $\mathrm{z}$ aktu prawa miejscowego bądź rozporządzenia, które to z kolei są wydawane na podstawie ustawowego upoważnienia (art. 92 i 94 Konstytucji RP). Takimi ograniczeniami na gruncie Prawa ochrony środowiska zgodnie $\mathrm{z}$ art. 130 mogą być: 1) poddanie ochronie obszarów lub obiektów na podstawie przepisów Ustawy z dnia 16 kwietnia 2004 r. o ochronie przy- może być wprowadzenie zakazu zabudowy - a to już z pewnością daleko idąca ingerencja, która może niekiedy wywołać nawet skutek wywłaszczeniowy (art. 17 ust. 1 pkt 7 i 8 oraz art. 24 ust. 1 pkt 8 i 9 u.o.p. ${ }^{10}$. W tym zakresie za wartościowy uznać należy pogląd Wojciecha Jakimowicza, który tłumaczy: „jeżeli prawo własności określonej nieruchomości w istocie ze względu np. na cechy tej nieruchomości (jak choćby jej położenie, obszar, ukształtowanie) nie pozwala na korzystanie z tej nieruchomości przez jej zabudowę, to brak możliwości zabudowy nieruchomości nie

\section{Konsekwencją ustanowienia parków narodowych} czy obszarów chronionego krajobrazu może być wprowadzenie zakazu zabudowy - a to już z pewnością daleko idąca ingerencja, która może niekiedy wywołać nawet skutek wywłaszczeniowy.

$\operatorname{rody}^{9}$ (u.o.p.) oraz 2) wyznaczenie obszarów cichych $\mathrm{w}$ aglomeracji oraz poza nią. Szczególnie istotne jest odesłanie do tej pierwszej ustawy, gdyż ograniczenia w korzystaniu z nieruchomości związane są z istnieniem lub utworzeniem parków narodowych i rezerwatów, parków krajobrazowych, obszarów chronionego krajobrazu, sieci obszarów Natura 2000 albo nieruchomości, na których znajdują się pomniki przyrody, stanowiska dokumentacyjne, a także użytki ekologiczne lub zespół przyrodniczo-krajobrazowy (art. 15, art. 17, art. 24, art. 33 i art. 45 tej ustawy). Szczegółowe wyliczenie tzw. obszarowych form ochrony przyrody zawarte jest w art. 6 u.o.p. i zawiera aż 10 punktów, co oznacza, że liczba różnorodnych ograniczeń może być znacząca. Takimi aktami mogą być także programy ochrony powietrza (art. 91 ust. 1 p.o.ś.) oraz programy ochrony środowiska przed hałasem (art. 119 ust. 1 u.o.p.). Nadto konsekwencją ustanowienia parków narodowych czy obszarów chronionego krajobrazu

9 T.j. Dz.U. 2018, poz. 142 ze zm. będzie mógł być rozpatrywany w kontekście uderzenia w istotę tego prawa, gdyż prawa tego w ogóle nie da się zbudować na prawie własności tej nieruchomości"11. Stąd przesądzające może być ustalenie treści ograniczanego prawa z punktu widzenia jego społeczno-gospodarczego przeznaczenia (art. 140 k.c.).

Niewątpliwie zatem nieruchomości wchodzące w skład tych obszarów poddawane są różnym, stopniowalnym ograniczeniom. Tymczasem w doktrynie oględnie podnosi się, że mogą one mieć poważny charakter $^{12}$.

10 Zob. Wyrok NSA z dnia 15 lipca 2016 r., II OSK 2809/14, LEX nr 2102247.

11 W. Jakimowicz, Wolność zabudowy w prawie administracyjnym, Warszawa 2012, s. 70; zob. także I. Zachariasz, Węzłowe konstrukcje prawne procesu planistycznego i budowlanego w rozwiązaniach projektu ustawy - Kodeks urbanistyczno-budowlany (wersja z 30 września 2016 r.), Prz.Leg. 2017, nr 1, s. 17.

12 K. Gruszecki, Prawo ochrony środowiska. Komentarz, Warszawa 2019, s. 343. 
Trybunał dostrzega też, że ograniczenia ustanawiane takimi aktami normatywnymi lub generalnymi ${ }^{13}$ mogą naruszać istotę prawa własności i innych praw majątkowych, a więc naruszać istotę prawa, o jakiej mowa w art. 31 ust. 3 i 64 ust. 3 Konstytucji RP. Jak słusznie podnosi TK: „W takim przypadku roszczenie o odszkodowanie lub wykup może być uznane za substytut istotnej części własności, użyt- nia 1997 r. o gospodarce nieruchomościami (u.g.n.) ${ }^{15}$, w którym stwierdza się, że: „Wywłaszczenie nieruchomości polega na pozbawieniu albo ograniczeniu"16. Identycznie ujęto to w art. 46 ogólnej ustawy wywłaszczeniowej z 1985 r. $^{17}$, art. 4 ustawy z 1958 r. ${ }^{18}$, a także art. 2 Prawa o postępowaniu wywłaszczeniowym z 1934 r. ${ }^{19}$ Po drugie, świadczy o tym gradacja publicznoprawnej ingerencji w prawo własności, która

\section{$\mathrm{W}$ polskim prawie wywłaszczeniowym od dawna} ekspropriacja była traktowana bądź jako odjęcie prawa własności (wywłaszczenie sensu stricto), bądź
też ograniczenie (wywłaszczenie sensu largo).

kowania wieczystego albo ograniczonego prawa rzeczowego; może zajmować, z ekonomicznego czy funkcjonalnego, ale nie strukturalnego, punktu widzenia, pozycję uprawnień właścicielskich czy uprawnień wchodzących w skład użytkowania wieczystego albo ograniczonego prawa rzeczowego. Roszczenie odszkodowawcze lub roszczenie o wykup stanowi w takim ujęciu niezbędne wyrównanie uszczerbku, wynikającego z ograniczenia własności lub innych praw majątkowych"14.

Jednocześnie brak próby dokonania kwalifikacji prawnej takiej ingerencji. Tymczasem nie wydaje się to aż tak skomplikowane. Skoro publicznoprawna ingerencja w prawo własności nie mieści się ramach konstytucyjnej zasady proporcjonalności, co TK sam dostrzega, to przyjmuje postać wywłaszczenia. Jest to oczywiste z kilku względów. Po pierwsze, w polskim prawie wywłaszczeniowym od dawna ekspropriacja była traktowana bądź jako odjęcie prawa własności (wywłaszczenie sensu stricto), bądź też ograniczenie (wywłaszczenie sensu largo). Explicite stanowi o tym wprost ab initio art. 112 ust. 1 Ustawy z dnia 21 sierp-

13 Zob. E. Szewczyk, M. Szewczyk, Generalny akt administracyjny, Warszawa 2014, s. 141

14 K 2/17, pkt 2.1. może przybrać postać ograniczenia nierodzącego odpowiedzialności odszkodowawczej, ograniczenia wymagającego rekompensaty i wreszcie wywłaszczenia. Wynika to z faktu, że ograniczenie prawa własności nie może doprowadzić do „wynaturzenia prawa własności”, pozbawienia tego prawa treści czy też nałożenia ciężaru nie do zniesienia, co zauważane jest w doktrynie francuskiej ${ }^{20}$, niemieckiej ${ }^{21}$ czy orzecznictwie ETPC, w którym silnie akcentowana jest zasada wyważenia, właściwej równowagi (fair balance) ${ }^{22}$.

15 T.j. Dz.U. 2018, poz. 2204 ze zm.

6 Zob. 124-126 u.g.n.

17 Ustawa z dnia 29 kwietnia 1985 r. o gospodarce gruntami i wywłaszczaniu nieruchomości, t.j. Dz.U. 1991, poz. 127 ze $\mathrm{zm}$.

18 Ustawa z dnia 12 marca 1958 r. o zasadach i trybie wywłaszczania nieruchomości, t.j. Dz.U. 1974, nr 10, poz. 64.

19 Dz.U. 1934, nr 86 poz. 776 ze zm.

20 Orzeczenia francuskiej Rady Konstytucyjnej z 13 grudnia 1985 r., 85-198 DC i z 9 kwietnia 1996 r., 96-373 DC, no. 22 (zob. także. L. Favoreu, L. Philip, Les grandes decisions du Conseil constitutionnel, Paris 1997, s. 477-478).

21 Np. I. von Münch, Staatsrecht II, Stuttgart 2002, s. 422.

22 Np. Wyrok ETPC z dnia 6 listopada 2007 r. w sprawie Bugajny i inni v. Polska, skarga nr 22531/05, LEX nr 534829; Wyrok ETPC z dnia 19 czerwca 2006 r. w sprawie Hutten-Czapska 
Wątpliwości co do tego nie było także tuż po odzyskaniu niepodległości przez Polskę. Takie rozumienie ekspropriacji zostało bowiem wyeksplikowane rzez Mariana Zimmermanna, którego uznać można za ojca polskiego prawa wywłaszczeniowego ${ }^{23}$, i podnoszone jest także w najnowszej doktrynie ${ }^{24}$. A zatem traktowanie ograniczenia naruszającego istotę danego prawa jako wywłaszczenia jest obecne w języku prawnym w głównej mierze do tego sprowadzają się rozważania TK o konstytucyjności kwestionowanego przepisu.

Niewątpliwie instytucje dawności spełniają wiele ważnych funkcji w systemie prawnym. Wielokrotnie w judykaturze pierwszoplanową przypisuje się funkcji stabilizacyjnej. Jak zauważa Trybunał, ze względu na konstytucyjną wartość, jaką jest porządek publiczny, należy unikać wzruszania długotrwałych stanów

\section{Ograniczenie prawa własności nie może doprowadzić do „wynaturzenia prawa} własności”, pozbawienia tego prawa treści
czy też nałożenia ciężaru nie do zniesienia.

i prawniczym. Jednakże kwestia ta nie była wprost podniesiona przez RPO i zapewne $z$ tego powodu TK się do niej nie odniósł. Jeśliby jednak patrzeć na ograniczenia $z$ art. 130 p.o.ś. jak na wywłaszczenie sensu largo, to zmieniłoby to punkt wyjścia dla stawianych przez TK tez, gdyż odszkodowanie w klasycznej koncepcji wywłaszczenia nie przedawnia się i jest ustalane $z$ urzędu.

Rygoryzm art. 129 ust. 4 p.o.ś. sprowadza się do faktu, że odszkodowanie w momencie orzekania przysługiwało w okresie dwóch lat od dnia wejścia w życie rozporządzenia lub aktu prawa miejscowego, a nie na przykład od momentu uzyskania wiadomości o zaistnieniu skutku ograniczającego lub uniemożliwiającego korzystanie z nieruchomości przez podmiot, który doznał takiego uszczerbku. Kwestionowana zbyt krótka długość prekluzji wymaga odniesienia się do ogólnej refleksji o instytucji dawności. I właśnie

v. Polska, skarga nr 35014/97, LEX nr 182154; Wyrok ETPC z dnia 29 listopada 2011 r., w sprawie Wiśniewska v. Polska, skarga nr 9072/02, LEX nr 1054818.

23 M. Zimmermann, Polskie prawo wywłaszczeniowe, Lwów 1939, s. 7.

24 Zob. S. Pawłowski, Modyfikacje klasycznej koncepcji wywłaszczenia a gwarancje praw jednostki, Poznań 2018, s. 682. faktycznych, gwarantując pewność i bezpieczeństwo obrotu prawnego. Nadto sąd podnosi, że nie należy ignorować funkcji ochronnej systemu prawnego, tzn. nie powinien on kreować stanu niepewności co do dochodzenia czy wykonywania praw lub uprawnień z jednej strony, a z drugiej nie powinien nakładać na inne podmioty obowiązków trwających ad infinitum. TK zauważa także, że dawność spełnia również funkcję wychowawczą, dyscyplinującą (animacyjną) i dowodową. Co jednak najważniejsze, dostrzega, że wskazane wyżej motywy dawności w pełni można stosować w stosunkach cywilnoprawnych, a więc w relacji horyzontalnej, czyli charakteryzującej się równorzędnością uczestników obrotu. Jednocześnie przesądza, i właśnie z tego względu glosowane orzeczenie ma przełomowe znacznie, że w relacji wertykalnej, a więc w takiej, w której podmiot publiczny w granicach i na podstawie prawa jednostronnie, to jest władczo orzeka o konsekwencjach dla drugiej strony stosunku prawnego, powyższe uzasadnienie instytucji dawności nie jest identyczne, a wręcz musi być inaczej ujmowane. Wynika to chociażby z faktu, że jego uzasadnieniem nie mogą być względy dowodowe. I właśnie to stanowisko zasługuje na szczególną aprobatę, gdyż w dotychczasowym orzecznictwie zasada pewności prawa, a więc funkcja stabilizacyjna, była 
często wystarczającym uzasadnieniem do uznania instytucji przedawnienia czy terminów zawitych na gruncie prawa publicznego za dopuszczalne.

Tymczasem TK stwierdza, że trudno uznać, iż z upływem lat utrudnione może zostać wykazanie istotnych faktów. Argumentuje to w ten sposób, że państwo nie tylko ma szczególną wiedzę o swojej sytuacji, w tym majątkowej (rejestry, ewidencje, spisy, archiwa), ale także dysponuje licznym zawodowym aparatem urzędniczym, na którym spoczywa szcze-
Po pierwsze, podkreślić należy, co rzadziej podnosi się w judykaturze, że utrata uprawnienia przez jeden podmiot oznacza korzyść drugiej strony, co można uznać za postępowanie nietyczne ${ }^{27}$, tu państwa, które co do zasady w takich relacjach jest podmiotem silniejszym. Wynika to z faktu, że organy władzy publicznej nie tylko tworzą prawo, ale także dysponują zawodowym aparatem urzędniczym do jego stosowania i egzekwowania. Po drugie, skutki upływu mogą przeczyć podstawowym założeniom konstrukcji praw

\section{W dotychczasowym orzecznictwie zasada pewności} prawa, a więc funkcja stabilizacyjna, była często wystarczającym uzasadnieniem do uznania instytucji przedawnienia czy terminów zawitych na gruncie prawa publicznego za dopuszczalne.

gólny obowiązek dbałości o interes państwa na wielu płaszczyznach. Zasadniczo w takim przypadku odpadają tradycyjne motywy (funkcje) korzystania $z$ instytucji dawności. Tym bardziej wtedy, gdy - jak w niniejszej sprawie - dawność jest ograniczeniem szeroko rozumianej rekompensaty za jednostronne, władcze doprowadzenie przez państwo do uszczerbku w sytuacji majątkowej jednostki.

Jak stwierdził TK wyroku z dnia 11 października 2012 r., mimo że żaden przepis Konstytucji RP nie normuje wprost kwestii dawności, to w orzecznictwie TK nie ma wątpliwości co do jej użyteczności dla systemu prawnego ${ }^{25}$, a wręcz stwierdza się, że prekluzja może służyć ochronie konstytucyjnych praw podmiotowych ${ }^{26}$. Niemniej w analizowanym orzeczeniu TK tylko pobieżnie odnosi się do istoty instytucji dawności. Argumentację tę należy pogłębić.

25 Wyrok TK z dnia 11 października 2012 r., OTK-A 2012, nr 9, poz. 105; zob. także przywołane tam orzecznictwo TK.

26 Wyrok TK z dnia 19 maja 2011 r., K 20/09, OTK-A 2011, nr 4, poz. 35 . podmiotowych, gdyż zasadzają się one na możliwości, a nie na obowiązku wykonywania swojego prawa ${ }^{28}$. Po trzecie, o ile za dominujący pogląd należy uznać, że długotrwałe stany faktyczne częściej odpowiadają prawu, niż są z nim sprzeczne, powinno być to wzruszalne domniemanie, a nie bezwzględna reguła. Po czwarte, o ile w prawie cywilnym (powszechnym) wartością nadrzędną staje się obiektywna przewidywalność skutków zachowań podmiotów prawa cywilnego, którą osiąga się poprzez usunięcie stanu niepewności prawnej w sytuacji, gdy przykładowo uprawniony przez dłuższy czas nie wykonuje swo-

27 P. Księżak, M. Pyziak-Szafnicka (red.), Kodeks cywilny. Komentarz. Część ogólna, Warszawa 2017, s. 823; S. Wójcik, Zagadnienia etyczne przedawnienia roszczeń (w:) M. Sawczuk (red.), Z zagadnień cywilnego prawa materialnego i procesowego, Lublin 1988, s. 141-160.

28 B. Kordasiewicz (w:) Z. Radwański (red.), System prawa prywatnego, t. 2: Prawo cywilne-część ogólna, Warszawa 2008 s. 575 . 
ich praw podmiotowych (funkcja stabilizacyjna) ${ }^{29}$, to w prawie publicznym (szczególnym) paremia ius civile vigilantibus scriptum est ze swej istoty nie może być wprost stosowana. Jak podniósł RPO: „Wymóg dbałości zainteresowanego o swoje prawa musi być odnoszony do zwyczajowego poziomu przeciętnego obywatela, który bez przekraczającego jego możliwości zaangażowania jest w stanie ocenić swoją sytuację prawną i podjąć adekwatne środki prawne". W świetle powyższego dwa lata na podjęcia działań niewątpliwie było zbyt krótkim terminem. Po piąte, w doktrynie kanie wielopoziomowego uzasadnienia skorzystania z instytucji dawności, to tym bardziej powinno być to regułą w prawie publicznym, charakteryzującym się nierównorzędnością jego uczestników. Po szóste, w ogólnym dyskursie o przedawnieniu czy prekluzji w prawie administracyjnym całkowicie pomija się fakt, że nawet niektóre roszczenia majątkowe w prawie cywilnym się nie przedawniają, np. roszczenie o zniesienie współwłasności (art. 220 k.c.), roszczenia windykacyjne i negatoryjne wynikające $\mathrm{z}$ własności nieruchomości (art. $223 \$ 1$ k.c.).

\section{W prawie publicznym (szczególnym) paremia} ius civile vigilantibus scriptum est ze swej istoty nie może być wprost stosowana.

prezentowane jest stanowisko, że żadnemu z uzasadnień instytucji dawności (funkcja stabilizacyjna, dyscyplinująca, dowodowa) nie można przyznać priorytetu, powinny być one spełnione wszystkie jednocześnie ${ }^{30}$, a żadna z nich nie powinna być stosowana pojedynczo takie uzasadnienie należy uznać za niewystarczające, a niekiedy instrumentalne. Powyższy postulat należy przyjąć jako wzorzec, punkt odniesienia, gdyż przy ich jednoczesnym spełnieniu można ją postrzegać jako niezbędny element porządku prawnego, niejako „wentyl bezpieczeństwa”, a więc konstrukcję uzasadnioną społecznie mimo negatywnych skutków dla jednej ze stron - w prawie administracyjnym dla administrowanego. Tomasz M. Pałdyna jest zwolennikiem poglądu, że na tę instytucję należy spojrzeć jak na element systemu ochrony praw podmiotowych ${ }^{31}$. Z powyższego wywieść można następujący wniosek: skoro w doktrynie prawa cywilnego postuluje się szu-

29 A. Jedliński, Komentarz do art. 117 Kodeksu cywilnego (w:) A. Kidyba (red.), Kodeks cywilny. Komentarz, t. 1: Czesść ogólna, Warszawa 2012, s. 729.

30 Tak np. B. Kordasiewicz, dz. cyt., s. 540-541.

31 T.M. Pałdyna, Przedawnienie w polskim prawie cywilnym, Warszawa 2012, s. 69.
RPO, a także TK dostrzegają, że na gruncie innych ustaw terminy zawite prawa materialnego są dłuższe, a ich długość często wynosi pięć lat ${ }^{32}$, co zdaniem TK „może służyć za swoisty standard, do którego mógłby odwołać się prawodawca, projektując zmianę art. 129 ust. 4 p.o.ś. w analizowanym zakresie" ${ }^{33}$. Jednakże warto by rozważyć, czy nie powinien to być 10-letni termin w przypadku pojawienia się skutku wywłaszczeniowego. Tu wzorzec może stanowić u.g.n. w zakresie długości przechowywania odszkodowania w depozycie sądowym (art. 118a ust. 3). Warty zaznaczenia jest fakt, że podobne ograniczenia w Prawie wodnym z 2001 r. nie przedawniały się (art. 187) ${ }^{34}$. Tymczasem nowe Prawo wodne przyjęło podobnie jak krytykowana regulacja dwuletni termin przedawnienia roszczeń

32 Np. art. 37 ust. 3 ustawy z dnia 27 marca 2019 r. o planowaniu i zagospodarowaniu przestrzennym, t.j. Dz.U. 2018, poz. 1945 ze zm.; taki termin jako maksymalny wskazuje też W. Piątek, Przedawnienie..., dz. cyt., s. 274; z kolei M. Wincenciak zachowuje wstrzemięźliwość we wskazywaniu ich długości a priori: M. Wincenciak, Przedawnienie..., dz. cyt., s. 361.

$33 \mathrm{~K} 2 / 17$, pkt. 2.4.2.

34 Ustawa z dnia 18 lipca 2001 r. - Prawo wodne, t.j. Dz.U. 2017, poz. $1121 \mathrm{ze} \mathrm{zm}$. 
$(\text { art. } 471)^{35}$, co czyni to rozwiązanie w świetle analizowanego orzeczenia niekonstytucyjnym. Taka zmiana wydaje się szczególnie niebezpieczna, gdyż stanowi wyraz przesuwania dopuszczalnych granic publicznoprawnej ingerencji w prawo własności. Autor jest zwolennikiem stanowiska reprezentowanego przez klasyczną doktrynę prawa administracyjnego, że nieznana jest konstrukcja przedawnienia o charakterze tworzącym prawa dla adresata ${ }^{36}$. Jednak jak wskazuje komentowany przepis, kwestie te stają się wyrazem polityki ustawodawcy. Całkowicie przy tym pomija się bycia poinformowanym, a w szerszym ujęciu zasada lojalności. Trudno przy tym tłumaczyć brak rekompensaty nieznajomością jednego ze źródeł prawa powszechnie obowiązującego, gdyż fikcja powszechnej znajomości prawa ze względu na specyfikę prawa administracyjnego musi być traktowana w sposób szczególny. Jest to tym bardziej trudne, gdy prawo staje się obszernym, niemożliwym do ogarnięcia zbiorem nadmiernie kazuistycznych norm ${ }^{38}$. Aktualność tego postulatu dostrzega RPO, który podnosi, że prawne ograniczenia korzystania z nieruchomo-

\section{Żadnemu z uzasadnień instytucji dawności (funkcja} stabilizacyjna, dyscyplinująca, dowodowa) nie można przyznać priorytetu; powinny być one spełnione wszystkie jednocześnie, a żadna z nich nie powinna być stosowana pojedynczo - takie uzasadnienie należy uznać za niewystarczające, a niekiedy instrumentalne.

możliwość wszczynania postępowań odszkodowawczych z urzędu, co zapewne stanowi konsekwencję uznawania takich uprawnień za roszczenia o charakterze cywilnoprawnym ${ }^{37}$, a to znajduje wprost odzwierciedlenie ust. 3-5 w art. 129 p.o.ś.

Na marginesie głównych rozważań wspomnieć należy o jeszcze jednym standardzie państwa prawnego. Skoro ograniczenie naruszające istotę prawa własności (wywłaszczenie sensu largo) dokonywane jest nie w drodze konkretyzacji normy ustawowej poprzez wydanie decyzji administracyjnej, ale w drodze przepisu prawa powszechnie obowiązującego, to naruszona może zostać inna ogólna reguła - prawo do

35 Ustawa z dnia 20 lipca 2017 r. - Prawo wodne, Dz.U. 2018, poz. $2268 \mathrm{ze} \mathrm{zm}$.

36 A. Wasilewski, Uplyw czasu jako zdarzenie prawne w prawie administracyjnym, „Państwo i Prawo” 1966, z. 1, s. 65.

37 Tak np. K. Gruszecki, Prawo ochrony..., dz. cyt., s. 346 i 351. ści nie od razu przedkładają się na faktyczne ograniczenia sposobu korzystania. Stąd też świadomość o zaistniałych zmianach może pojawić się dopiero w momencie, w którym może nastąpić chęć zmiany sposobu zagospodarowania lub zabudowy nieruchomości. Kwestia ta może także stać się problemem dla osoby, która stała się nabywcą po zaistnieniu biegu terminu, o którym nie wie. Nadto uciążliwość stanowiąca podstawę odszkodowania może być zmienna w czasie. RPO zasadnie też zauważa, że dwuletni termin jest iluzoryczny, stanowi pozór prawa, gdyż zniweczenie istotnego atrybutu prawa własności (tu możliwości korzystania z nieruchomości lub z jej części) nie jest automatycznie powiązane z odpowiednią

38 Tak Z. Duniewska, Fikcja powszechnej znajomości prawa w prawie administracyjnym (w:) E. Knosala, A. Matan, G. Łaszczyca (red.), Prawo administracyjne w okresie transformacji ustrojowej, Kraków 1999, s. 27 i n. 
kompensacją ${ }^{39}$, a krótki termin na złożenie wniosku o odszkodowanie oznacza, że adresaci normy prawnej mogą z tej regulacji nigdy nie skorzystać. Wiązać się
Rzecz bowiem w tym, że publicznoprawnej ingerencji w prawa własności nie towarzyszy automatyczne obowiązek kompensacyjny. Całkowicie przy tym pomija

\section{Autor jest zwolennikiem stanowiska reprezentowanego przez klasyczną doktrynę prawa administracyjnego, że nieznana jest konstrukcja przedawnienia o charakterze tworzącym prawa dla adresata.}

to może z przekreśleniem funkcji, jakie ona ma spełniać, w szczególności zgodnie z art. 20 Konstytucji RP. Artykuł 129 ust. 1 p.o.ś. stanowi zatem jedynie pozór ochrony praw majątkowych. A przecież z zasady demokratycznego państwa prawnego wynika zakaz kreowania instytucji pozornych ${ }^{40}$. Zgodzić należy się zatem $\mathrm{z}$ tezą, że tak krótki termin $\mathrm{w}$ istocie oznacza, że państwo liczy na to, iż jednostka nie złoży takiego wniosku, a w tle pojawiają się względy budżetowe. Tym samym analizowany przepis można postrzegać także przez pryzmat nacjonalizacji, właśnie ze względu na iluzoryczność rekompensaty ${ }^{41}$.

Potwierdzeniem powyższego sposobu myślenia jest stanowisko Komisji Ochrony Środowiska, Zasobów Naturalnych i Leśnictwa, która wniosła o odrzucenie projektu nowelizacji tego przepisu z uwagi na stan niepewności w realizacji budżetów państwa i jednostek samorządu terytorialnego. Będąc zatem za utrzymaniem tak krótkiego terminu, pominęła konstytucyjne aspekty obowiązującego ograniczenia. Tymczasem sama formuła uzyskiwania rekompensaty na wniosek, a nie ex officio budzi już uzasadnione wątpliwości.

39 Zob. uzasadnienie Wyroku TK z dnia 12 stycznia 2000 r., P 11/98, OTK 2000, nr 1, poz. 3.

40 Wyrok TK z dnia 18 lipca 2013 r., SK 18/09, OTK-A 2013, nr 6, poz. 80 .

41 Zob. S. Pawłowski, Wywłaszczenie z mocy prawa (ex lege) a nacjonalizacja - refleksje w przedmiocie publicznoprawnych ingerencji w prawo własności, „Ruch Prawniczy, Ekonomiczny i Socjologiczny” 2019, nr 1, s. 97. się następujący dylemat: jeśli państwa nie stać na realizację określonego celu publicznego, to może nie jest on tego wart, gdyż narusza to chociażby zasadę równości wobec prawa, którą uznaje się za fundament państwa prawnego. W przypadku ochrony środowiska trudno uznać, że nie jest to cel doniosły społecznie, niemniej wartością chronioną konstytucyjnie jest także prawo własności, a wszelka ingerencja w to prawo powinna być dokonywana nie tylko z uwzględnieniem zasady proporcjonalności, ale także wspomnianej zasady równości wobec prawa, w tym równego ponoszenia ciężarów publicznych.

W glosowanym wyroku pojawia się także wątek kontrowersyjnego wzorca, który po roku 2000 r. stał się wielokrotnie podstawą nieuwzględniania wielu zarzutów naruszenia Konstytucji RP. Mowa tu o zasadzie równowagi budżetowej - zasadzie niewyrażonej wprost w Konstytucji $\mathrm{RP}^{42}$, w sposób nieuzasadniony stawianej wielokrotnie przed innymi, wprost w niej zawartymi, w tym przed zasadą równości wobec prawa $^{43}$. Tymczasem w analizowanym wyroku TK stwierdził, co również należy uznać za szczególnie doniosłe, że przewidywalność budżetowa nie stanowi wystarczającej samodzielnej przesłanki uznania tego przepisu za konstytucyjny. Jest to tym bardziej

42 Tak samo A. Hanusz, Równowaga budżetowa a zasady prawa, „Państwo i Prawo” 2015, nr 9, s. 33.

43 Tak np. w Wyroku TK z dnia 24 października 2009 r., SK 36/07, OTK-A 2009, nr 10, poz. 151. 
ważne, że „równowaga budżetowa jest regułą fiskalną o postulatywnym, a nie normatywnym charakterze" 44 .

Reasumując, w odniesieniu do glosowanego orzeczenia Trybunał Konstytucyjny nie ma wątpliwości, że termin zawity to instytucja surowa dla uczestników obrotu prawnego, tym bardziej że nie podlega on co do zasady zawieszeniu, wstrzymaniu czy przerwaniu, a jego upływ uwzględniany jest z urzędu, nie na zarzut. Stawia przy tym tezę, że instytucja ta wykorzystywana jest przede wszystkim dla realizacji celów o doniosłości ogólnospołecznej ${ }^{45}$. W kwestii tej jednak bliżej się nie logiczne, o którym mówi W. Jakimowicz, mogłoby przemawiać za dokonaniem wykładni contra lege, a zatem daniem prymatu wykładni celowościowej i niestosowaniem tego zbyt krótkiego terminu ${ }^{48}$, gdyż literalne brzmienie przepisu może prowadzić do rażąco niesprawiedliwych rozstrzygnięć ${ }^{49}$. Takiej rozproszonej kontroli konstytucyjnej może dokonywać sądownictwo administracyjne, co miało miejsce chociażby w wyroku NSA z dnia 2 czerwca 2017 r. ${ }^{50}$ W świetle tego orzeczenia należałoby ocenić, czy znowelizowany art. 129 ust. 4 p.o.ś. również spełnia zarzuty

\section{Publicznoprawnej ingerencji w prawo własności nie towarzyszy automatyczne obowiązek kompensacyjny.}

wypowiada, a szkoda, bowiem taki interes publiczny z pewnością jest stopniowalny i nie stanowi wartości bezwzględnej - tym samym nie zyskuje prymatu nad innymi wartościami wyrażonym w Konstytucji RP. Te końcowe uwagi są o tyle istotne, że wykonanie tego wyroku nastąpiło poprzez nowelizację art. 129 ust. 4 p.o.s. ${ }^{46}$, która wydłużyła wskazany termin zaledwie o rok. Trudno uznać, że ten nowy termin nie uchybia zarzutom stawionym przed RPO i TK. Zdecydowanie łatwiej bowiem przypisać temu rozwiązaniu instrumentalizm przyświecający pierwotnej wersji. Zdumiewa przy tym fakt, że wprowadzony trzyletni termin jest krótszy, niż wynikałoby to ze zmian proponowanych wniesionym do Sejmu projektem $z$ dnia 6 lipca 2016 r. Ustawy o zmianie ustawy - Prawo ochrony środowiska ${ }^{47}$.

Zastanowić się warto, jak obecnie traktować art. 129 ust. 4 p.o.ś. $Z$ jednej strony silne uzasadnienie aksjo-

\footnotetext{
44 A. Gorgol, Równowaga budżetowa w świetle orzecznictwa Trybunału Konstytucyjnego, „Państwo i Prawo” 2014, nr 9 , s. 35 .

45 Tak samo J. Ignatowicz (w:) S. Grzybowski (red.), System prawa cywilnego, t. 1: Część ogólna, Wrocław 1985, s. 843 i n.

46 Art. 1 Ustawy nowelizującej z dnia 22 lutego 2019 r., Dz.U. 2019, poz. 452.

47 Druk nr 774, Sejm RP VIII kadencji.
}

stawiane w glosowanym wyroku, w szczególności czy nie odbiega w żaden sposób od istotnej treści przepisu art. 129 ust. 4 p.o.ś. w pierwotnym brzmieniu. Należy go bowiem odczytywać w duchu art. 20 oraz art. 64 ust. 1 Konstytucji RP w związku z art. 31 ust. 3 Konstytucji RP, które to ujęcie jest bliskie Autorowi ${ }^{51}$. Jednakże z drugiej strony nakazana jest ostrożność, gdyż zasadniczo wyraz prawotwórczy orzeczeń Trybunału ma jedynie jego sentencja, a nie uzasadnienie. Nadto ustawodawca wykonał jednak zalecenie sądu i wydłużył termin do składania wniosków odszkodowawczych o rok, tj. o jedną trzecią. Stąd przy uwzględnieniu zasady domniemania konstytucyjności przepisów ustawowych organy administracji publicznej

48 W. Jakimowicz, Wykładnia w prawie administracyjnym, Kraków 2006, s. 551-552, zob. także Wyrok TK z dnia 28 czerwca 2000 r., K 25/99, OTK 2000, nr 5, poz. 141, pkt. IV.2.

49 L. Morawski, Wykładnia w orzecznictwie sądów, Toruń 2002, s. 101.

50 Por. uzasadnienie Wyroku NSA z dnia 2 czerwca 2017 r., I OSK 26/17, LEX nr 2338649.

51 W ocenie M. Wincenciaka określenie terminu przedawnienia powinno być wypadkową ocen i analiz stosunku prawnego, z którym związane jest przedawnienie, a jego wskazanie wymaga namysłu i wielkiej precyzji. Ostatecznie opowiada się za powściągliwością w nadmiernym skracaniu terminów; M. Wincenciak, Przedawnienie..., dz. cyt., s. 360-361. 
powinny stosować wykładnię językową art. 129 ust. 4 p.o.ś., która nie budzi wątpliwości, a znowelizowany przepis odbiega od istotnej treści w brzmieniu pierwotnym. W glosowanym wyroku zostało bowiem wprost stwierdzone, że nie jest rolą Trybunału wskazywanie
Jakimowicz W., Wolność zabudowy w prawie administracyjnym, Warszawa 2012.

Jedliński A., Komentarz do art. 117 Kodeksu cywilnego (w:) A. Kidyba (red.), Kodeks cywilny. Komentarz, t. 1: Część ogólna, Warszawa 2012.

\section{Wszelka ingerencja w prawo własności powinna być dokonywana nie tylko $\mathrm{z}$ uwzględnieniem} zasady proporcjonalności, ale także zasady równości wobec prawa, w tym równego ponoszenia ciężarów publicznych.

ustawodawcy konkretnych rozwiązań normatywnych. Nadto nie można pomijać art. 7 Konstytucji RP, a więc zasady praworządności, gdyż naruszałoby to zasadę pewności prawa będącą jedną z kluczowych emanacji państwa prawnego. Jednocześnie zauważone wątpliwości powinny skłonić sądy administracyjne do ponownego złożenia zapytania do TK o zbadanie konstytucyjności wprowadzonego rozwiązania.

\section{Bibliografia}

Duniewska Z., Fikcja powszechnej znajomości prawa w prawie administracyjnym (w:) E. Knosala, A. Matan, G. Łaszczyca (red.) Prawo administracyjne $w$ okresie transformacji ustrojowej, Kraków 1999.

Favoreu L., Philip L., Les grandes decisions du Conseil constitutionnel, Paris 1997.

Gorgol A., Równowaga budżetowa w'świetle orzecznictwa Trybunału Konstytucyjnego, „Państwo i Prawo” 2014, nr 9.

Gruszecki K., Prawo ochrony środowiska. Komentarz, Warszawa 2019.

Grzybowski S. (red.), System prawa cywilnego, t. 1: Część ogólna, Wrocław 1985.

Hanusz A., Równowaga budżetowa a zasady prawa, „Państwo i Prawo" 2015, nr 9.

Jakimowicz W., Wykładnia w prawie administracyjnym, Kraków 2006.
Księżak P., Pyziak-Szafnicka M. (red.), Kodeks cywilny. Komentarz. Część ogólna, Warszawa 2017.

Morawski L., Wykładnia w orzecznictwie sądów, Toruń 2002 von Münch I., Staatsrecht II, Stuttgart 2002.

Pałdyna T.M., Przedawnienie w polskim prawie cywilnym, Warszawa 2012.

Pawłowski S., Modyfikacje klasycznej koncepcji wywłaszczenia a gwarancje praw jednostki, Poznań 2018.

Pawłowski S., Wywłaszczenie z mocy prawa (ex lege) a nacjonalizacja - refleksje w przedmiocie publicznoprawnych ingerencji w prawo własności, „Ruch Prawniczy, Ekonomiczny i Socjologiczny" 2019, nr 1.

Piątek W., Przedawnienie w prawie administracyjnym, Poznań 2018.

Radwański Z. (red.), System prawa prywatnego, t. 2: Prawo cywilne-część ogólna, Warszawa 2008.

Szewczyk E., Szewczyk M., Generalny akt administracyjny, Warszawa 2014.

Wasilewski A., Upływ czasu jako zdarzenie prawne w prawie administracyjnym, „Państwo i Prawo” 1966, z. 1.

Wincenciak M., Przedawnienie w polskim prawie administracyjnym, Warszawa 2019.

Wójcik S., Zagadnienia etyczne przedawnienia roszczeń (w:) M. Sawczuk (red.), Z zagadnień cywilnego prawa materialnego i procesowego, Lublin 1988.

Zachariasz I., Węzłowe konstrukcje prawne procesu planistycznego i budowlanego $w$ rozwiązaniach projektu ustawy-Kodeks 
urbanistyczno-budowlany (wersja z 30 września 2016 r.), „Przegląd Legislacyjny" 2017, nr 1.

Zimmermann M., Polskie prawo wywłaszczeniowe, Lwów 1939.

\section{Orzecznictwo}

Wyrok ETPC z dnia 19 czerwca 2006 r. w sprawie Hutten-Czapska v. Polska, skarga nr 35014/97, LEX nr 182154.

Wyrok ETPC z dnia 6 listopada 2007 r. w sprawie Bugajny i inni v. Polska, skarga nr 22531/05, LEX nr 534829.

Wyrok ETPC z dnia 29 listopada 2011 r., w sprawie Wiśniewska v. Polska, skarga nr 9072/02, LEX nr 1054818.

Wyrok TK z dnia 28 czerwca 2000 r., K 25/99, OTK 2000, nr 5, poz. 141.

Wyrok TK z dnia 24 października 2009 r., SK 36/07, OTK-A 2009, nr 10, poz. 151.

Wyrok TK z dnia 19 maja 2011 r., K 20/09, OTK-A 2012, nr 9, poz. 105

Wyrok TK z dnia 11 października 2012 r., SK 18/10, OTK-A 2012, nr 9, poz. 105.

Wyrok TK z dnia 18 lipca 2013 r., SK 18/09, OTK-A 2013, nr 6, poz. 80

Wyrok TK z dnia 7 marca 2018 r., K 2/17, OTK-A 2018, nr 13.

Wyrok NSA z dnia 15 lipca 2016 r., II OSK 2809/14, LEX nr 2102247.

Wyrok NSA z dnia 2 czerwca 2017 r., I OSK 26/17, LEX nr 2338649.

\section{Akty prawne}

Rozporządzenie Prezydenta Rzeczypospolitej z dnia 24 września 1934 r. Prawo o postępowaniu wywłaszczeniowem, Dz.U. 1934, nr 86 poz. 776 ze zm.
Ustawa z dnia 12 marca 1958 r. o zasadach i trybie wywłaszczania nieruchomości, t.j. Dz.U. 1974, nr 10 poz. 64.

Ustawa z dnia 29 kwietnia 1985 r. o gospodarce gruntami i wywłaszczaniu nieruchomości, t.j. Dz.U. 1991, poz. 127 z późn. $\mathrm{zm}$.

Ustawa z dnia 21 sierpnia 1997 r. o gospodarce nieruchomościami, t.j. Dz.U. 2018, poz. 2204 z późn zm.

Ustawa z dnia 27 kwietnia 2001 r. - Prawo ochrony środowiska, t.j. Dz.U. 2018, poz. 799 z późn. zm.

Ustawa z dnia 18 lipca 2001 r. - Prawo wodne, t.j. Dz.U. 2017, poz. $1121 \mathrm{z}$ późn. $\mathrm{zm}$.

Ustawy z dnia 27 marca 2019 r. o planowaniu i zagospodarowaniu przestrzennym, t.j. Dz.U. 2018, poz. 1945 ze zm.

Ustawa z dnia 16 kwietnia 2004 r. o ochronie przyrody, t.j. Dz.U. 2018, poz. 142 z późn zm.

Ustawa z dnia 20 lipca 2017 r. - Prawo wodne, Dz.U. 2018, poz. 2268 ze zm.

Ustawa z dnia 22 lutego 2019 r. o zmianie ustawy - Prawo ochrony środowiska, Dz.U. 2019, poz. 452.

\section{Pozostałe}

Projekt z dnia 29 grudnia 2010 r., nr druku 3942 Sejmu RP VI kadencji, http://orka.sejm.gov.pl/Druki6ka.nsf/0/8F21 C6C714261B99C1257849003B79D6/\$file/3942.pdf (dostęp 13.11.2019).

Wniosek Rzecznika Praw Obywatelskich z dnia 24 lutego 2017 r., sygn. IV.7002.55.2014.ZA, https://www.rpo.gov.pl/pl/content/ rzecznik-zlozyl-wniosek-do-trybunalu-konstytucyjnego-w-sprawie-terminu-ubiegania-sie-o-rekompensate (dostęp 9.07.2019). 